\title{
Pemanfaatan Daun Kering Sebagai Tempat Pembibitan Ikan dengan Additive PVAc \& Resin
}

\author{
https://doi.org/10.32509/am.v4i1.1111
}

\section{Istianto Budhi Rahardja ${ }^{1)}$, Dharu Dewi ${ }^{2)}$, Indriasari ${ }^{3)}$, Ade Muslimat ${ }^{4)}$, Sukarman ${ }^{5}$, Khoirudin'), Nana Rahdiana $^{7}$, Safril ${ }^{8)}$, Sa Diyah El Adawiyah"), Anwar Ilmar Ramadhan $^{10)}$}

\author{
${ }^{1)}$ Teknologi Pengolahan Hasil Perkebunan, Politeknik Kelapa Sawit Citra Widya Edukasi, \\ Jl. Gapuran 8, Rawa Banteng, Setu, Bekasi - Inodonesia \\ 2) Pusat Kajian Sistem Energi Nuklir, BATAN, \\ Jl. Kuningan Barat, Mampang Prapatan, Jakarta - Indonesia \\ 3) Teknik Sipil, Fakutas Teknik, Universitas Krisna Dwipayana, \\ Jatiwaringin, Pondok Gede - Indonesia \\ ${ }^{4)}$ Ekonomi Bisnis, Fakultas Ekonomi, Universitas Serang Raya, \\ Jl. Raya Cilegon No.Km. 5, Kota Serang, Banten - Indonesia \\ 5) Jurusan Teknik Mesin, Fakultas Teknik, Sekolah Tinggi Teknologi Watsu Kancana, \\ Jl. Alternative Bukit Indah, Purwakarta - Indonesia \\ ${ }^{6,7)}$ Fakultas Teknik \& Informatika, Universitas Buana Perjuangan Karawang, \\ Jl. H.S. Ronggowaluyo, Teluk Jambe, Karawang - Indonesia \\ ${ }^{8)}$ Fakultas Teknik, Politeknik STMI Jakarta, \\ Jl. Letjend Suprapto No.26, RT.10/RW.5, Cemp. Putih, Jakarta - Indonesia \\ ${ }^{9,10)}$ Jurusan Teknik Mesin, Fakultas Teknik, Universitas Muhammadiyah Jakarta, \\ Jl. K.H. Ahmad Dahlan, Tangerang Selatan, Banten - Indonesia \\ Email Korepondensi : istianto.rahardja@gmail.com
}

\begin{abstract}
Leaves dry as waste from plants and the trees not berproduktif again.Dried leaves dark brown and the longer will be destroyed / damaged without benefit.The use of dried leaves not limited only as fertilizer compost, but can be used as some form objects to use for life. Objects that can be made from the dried leaves is particles board, furniture, a buoy, and other objects that be used as a nursery fish.The use of dried leaves as a nursery fish can be done by binding dried leaves use of adhesive which can unite between particles composite dried leaves, and can withstand the force water are in it. A fastener material can also hold water (resistance. from happening to leakage in place a nursery fish.Dried leaves as a nursery fish having elastistias and strength good enough, thus it can be used in a relatively long enough. The use of the dried leaves as a nursery fish can also provide value in $3 r$ (reduce, recylce, reuse) government programs to reduce the capacity of waste is happening in our environment. Keywords: dried leaves, , waste, additive
\end{abstract}

Abstrak - Daun kering sebagai waste dari tumbuhan dan pepohonan yang tidak berproduktif lagi. Daun kering berwarna coklat tua dan semakin lama akan menjadi hancur/rusak tanpa manfaat. Pemanfaatan daun kering tida hanya sebatas sebagai pupuk kompos, akan tetapi dapat dijadikan beberapa wujud benda yang dipergunakan untuk kehidupan. Benda yang dapat dibuat dari daun kering adalah partikel board, furniture, pelampung, maupun benda lain yang dipergunakan sebagai tempat pembibitan ikan. Pemanfaatan daun kering sebagai tempat pembibitan ikan dapat dilakukan dengan pengikatan daun kering menggunakan bahan perekat yang dapat menyatukan antar partikel komposit daun kering, serta dapat menahan gaya air yang berada di dalamnya. Bahan pengikat juga dapat menahan air (resistance water) supaya tidak terjadi kebocoran pada tempat pembibitan ikan. Daun kering sebagai tempat pembibitan ikan memiliki elastistias dan kekuatan yang cukup baik, sehingga dapat dipergunakan dalam waktu yang relatif cukup lama. Pemanfaatan daun kering sebagai tempat pembibitan ikan juga dapat memberikan value dalam 3R (Reduce, Recylce, Reuse) program pemerintah untuk mengurangi kapasitas waste yang terjadi di lingkungan kita.

Kata kunci : Daun Kering, Limbah, Additive 


\section{PENDAHULUAN}

Daun kering adalah limbah hasil produksi dari tumbuhan/tanaman yang dipergunakan untuk memperoleh produk tanaman berupa bunga, buah, maupun produk yang lainnya. Daun merupakan indikasi sebuah tanaman/pohon hidup secara baik dan produktif (Hendrasarie, 2007). Tanaman/tumbuhan/pohon yang kekurangan nutrisi, maupun terserang oleh hama penyakit, secara mudah dapat terlihat dari daun yang dimilikinya (Riskitavani dan Purwani, 2013) . Daun pepohon yang kekurangan nutrisi akan terlihat kuning dan tidak berwarna hijau, mudah layu, sedangkan daun yang terjangkit hama penyakit akan terlihat tidak normal, berkerut, tidak sama ukuran/dimensi antar bagian kanan dan kiri, serta masih banyak lagi indikasi daun sebagai prediksi dini di dalam tanaman (Nusantara dkk, 2017).

Akhir daun yang produktif, terserang penyakit, abnormal, normal dan sebagainya adalah menjadi daun kering. Daun kering secara umum tidak memiliki produktif serta memiliki kecenderungan menjadi produk sampingan yang tidak memiliki nilai (Wandi, 2015). Daun kering menjadi limbah/waste yang merugikan, memberikan efek kotor, tidak terawat, serta menjadi berbau (Amran, 2015). Daun kering menjadi permasalahan dengan berbagai fenomena serta kakteristik yang dimilikinya. Pemerintah mencanangkan program 3R (Reduce, Recycle, dan Reuse) dari limbah yang ada termasuk daun kering (Peraturan Menteri KLH No 13, 2012). Fenomena daun kering menjadi sangat bermasalah dan menjadi perhatian. Daun kering sampai saat ini dipergunakan sebagai pupuk kompos dengan penimbunan tanah dengan waktu yang cukup signifikan (Setyorini dkk, 2006).

Pemanfaatan lain adalah hanya sebagai bahan bakar berbentuk biomassa. Beberapa teknologi yang telah dilakukan untuk mengurangi adanya permasalahan waste dalam bentuk lain adalah dalam bentuk produk nyata yang dapat dipergunakan sebagai pot tanaman, partikel board, furniture (Rahardja dan Ramadhan, 2019). Dalam perkembangan teknologinya bahwa daun kering dibuat menjadi bahan komposit yang dipergunakan untuk membuat partisi bangunan, peredam panas yang dipergunakan sebagai roof building, maupun yang lain. Teknologi yang cukup baik saat ini dapat memberikan bahwa daun kering adalah sebagai limbah alam yang memiliki karakteristik serta mudah pembentukannya. Dalam hal ini daun kering dapat dibentuk sesuai dengan kebutuhan dan dapat dipergunakan sebagai tempat pembibitan ikan, yang saat ini masih dalam bentuk kaca (aquarium), wadah plastik, maupun tambak/kolam pembibitan ikan. Komposit dari daun kering menjadi salah satu alternatif menjadi tempat pembibitan ikan dengan bentuk, modifikasi serta kebutuhannya.

\section{Daun Kering}

Daun kering hasil produktivitas pepohonan dan tanaman adalah limbah yang tidak produktif dan hanya sebagai pupuk kompos saja. Daun kering dapat disebabkan karena serangan gulma, hama penyakit, perubahan iklam, serta masih banyak sekali penyebabnya dan akan gugur ke tanah menjadi limbah/waste. Daun kering tidak hanya satu atau beberapa daun saja, namun terdapat pula daun kering yang masih berada pada pohon utuh seluruhnya menjadi kering. Ini diakibatkan karena serangan hama penyakit pada pohon (Khuluq, 2012). Daun kering secara alami akan berjatuhan disekitar pohonnya, dengan warna coklat tua, bersifat rapuh, dan mudah diuntuk diurai. Adapun gambar daun kering dapat dilihat pada gambar di bawah ini.

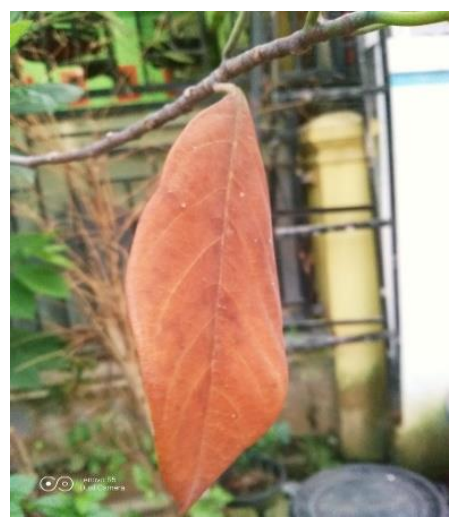

a.

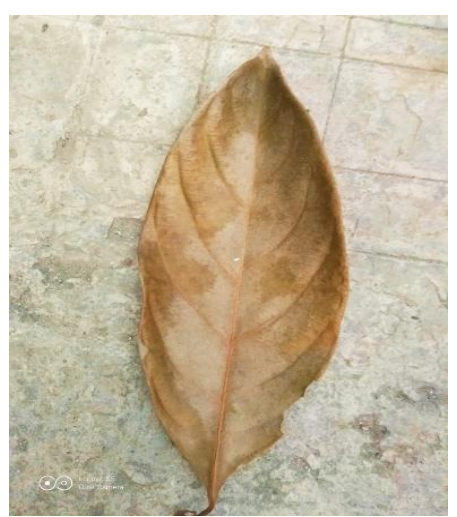

b.

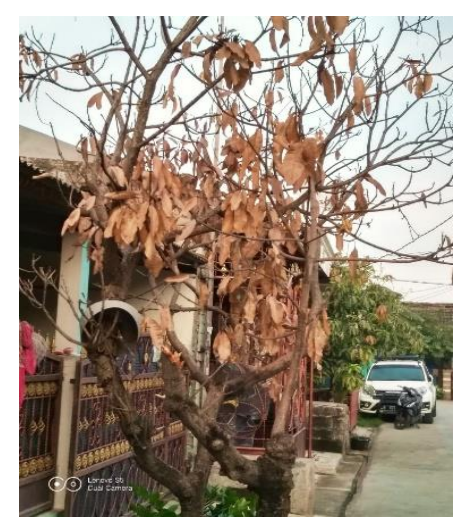

c.

Gambar 1. Daun kering, Masih berada di pohon (a), daun kering jatuh (b), seluruh pohon kering (c). 


\section{R (Reuse, Reduce, Recycle)}

Pemerintah dalam menanggulangi terhadap permasalahan sampah yang semakin lama semakin lama bertambah besar jumlahnya, tanpa adanya pengolahan yang dapat menurunkan kapasitasnya, maka pemerintah mencanangkan program 3R (Reduce, Recycle, dan Reuse) dari limbah/sampah (waste) yang terdapat disekitar kita (Peraturan Presiden Indonesia No. 97/2017). Beberapa Tempat Pembuangan Sampah Akhir telah melakukan program $3 \mathrm{R}$ untuk menekan kapasitas waste rumah tangga. Beberapa pemanfaatan dari limbah rumah tangga dipergunakan sebagai pupuk kompos yang berasal dari limbah rumah tangga berupa sisa makanan, tumbuhan, dan lain-lain; terdapat pula sebagai energi listrik dari biogas limbah yang dihasilkan dari limbah yang menjadi gas metan, serta beberapa produk rumah tangga lain yang bersifat plastik, logam, kaca dan lain-lain untuk di daur ulang kembali menjadi beberapa produk rumah tangga. Program ini sangat didukung oleh warga, masyarakat serta pelaku industri dalam mengurangi dan penekan jumlah sampah yang ada, sehingga menjadi go green dilingkungan kita.

\section{METODOLOGI PELAKSANAAN}

Skema yang dipergunakan dalam pembuatan pembibitan ikan dari daun kering adalah sebagai berikut.

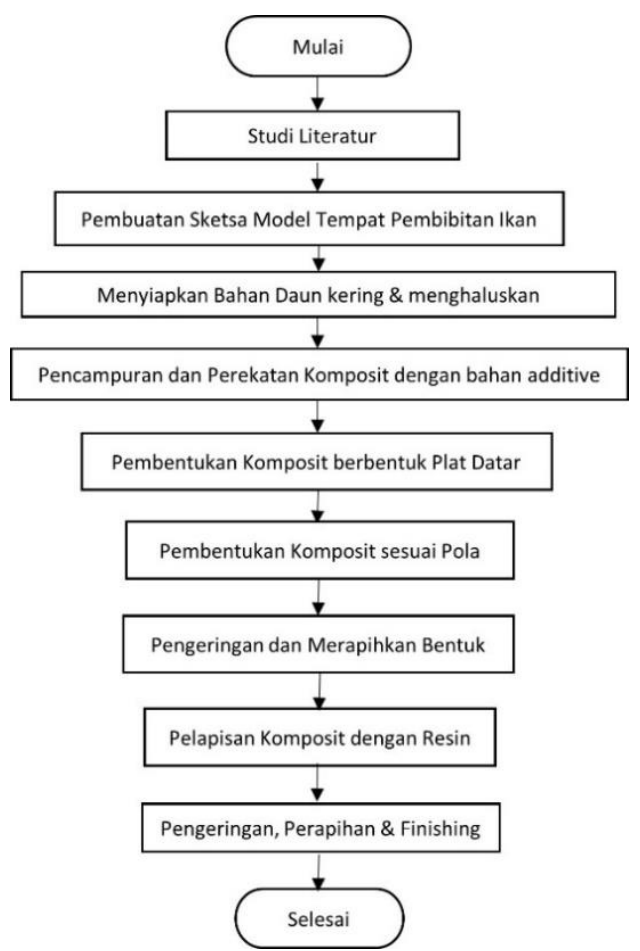

Gambar 2. Skema Pembuatan Pembibitan Ikan Dengan Daun Kering.

Tahap awal yang dilakukan oleh kami dalam pembuatan pembibitan ikan dari daun kering adalah mencari dan literatur dalam proses pemanfaatan limbah daun kering yang dapat dimanfaatkan kembali menjadi produk berguna. Dalam proses ini kami mencari proses dan produk yang terbuat dari bahanbahan/daun kering (natural fiber) serta bahan-bahan perekat dan pengikat untuk memperkuat bagian satu dengan yang lain. Tahap selanjutnya dilakukan pembuatan sketsa, ukuran, model berbentuk silinder dengan ukuran diamter $25 \mathrm{~cm}$ dan tinggi $20 \mathrm{~cm}$. Setelah telah ditentukan ukurannya, kemudian dibuat pola/cetakan dengan bahan plastik. Selanjutnya kami mempersiapkan bahan-bahan daun kering, kemudian dilakukan penghalusan mempergunakan mesin penghalus. Hasil daun yang telah dihaluskan akan berbentuk butiran-butiran halus. Untuk mendapatkan bahan baku yang seragam, maka dapat dilakukan penyaringan dengan alat penyaring dengan mesh/ukuran penyaringan yang ditentukan. Kemudian dilanjutkan dengan memberikan campuran bahan baku dengan bahan perekat berupa polyvinyl acetate (PVAc) dengan perbandingan bahan baku dan PVAc adalah 1:4. Campurkan secara merata dari kedua bahan tersebut. Apabila masih terdapat butiran bahan baku yang belum tercampur, maka dapat diberikan tambahan air sebesar 5-10\% dari bahan baku. Setelah tercampur secara merata, kemudian buatlah bahan adonan menjadi plat datar dengan membentuk dan menekan bahan adonan dengan rolling pin kayu (penggiling adonan kue) berbentuk silinder dengan bagian atas dan bawah 
diberikan plastik untuk tidak lengket/terikut pada rolling pin kayu. Usahakan bagian yang satu dengan yang lain menjadi rata (tebal $\pm 2 \mathrm{~mm}$ ), kemudian bentuk menjadi plat. Selanjutnya bentuk plat dari bahan adonan dibentuk sesuai pola/model silinder yang telah dibuat, dan diusahakan seluruh bagian pola/model tertutupi oleh adonan. Selanjutnya dilakukan proses pengeringan pada sinar matahari. Setelah kering adonan dan pola/model dapat dipisahkan. Tahap selanjutnya adalah memeriksa kembali hasil cetakan dari pola/model silinder tersebut, kemudian dibersihkan dan dirapihkan bagian yang tidak sama maupun yang berlebihan. Tahap terakhir adalah melapisi bahan adonan dengan resin epoxy dengan bahan hardener dengan perbandingan 1:1. Campurkan resin epoxy dan hardener secara merata dengan waktu antara 2-3 menit. Setelah bercampur secara merata, maka dilapisi pada mempergunakan kuas ataupun alat lain kepada hasil cetakan adonan. Keringkan hasil pelapisan resin dan hardener tersebut pada sinar matahari. Setelah benar-benar kering, maka dicoba dengan memasukan air ke dalam tempat pembibitan tesebut beberapa hari. Periksa kembali kebocoran dari tempat pembibitan tersebut. Setelah diperiksa tidak ada kebocoran, maka bibit ikan dapat diletakkan pada tempat pembibitan ikan dari daun kering.

\section{HASIL DAN PEMBAHASAN}

Dalam proses pembuatan tempat pembibitan ikan dilakukan secara sederhana dan maunual/tidak mempergunakan teknologi modern dan canggih. Tahapan dalam pembuatan tempat pembibitan ikan adalah sebagai berikut:

- Mempersiapkan alat dan bahan. Alat yang dipergunakan untuk pembuatan tempat pembibitan ikan berupa : botol kaca silinder yang dipergunakan untuk membentuk komposit menjadi pipih seperti plat datar, plastik dipergunakan untuk alas penekanan dengan menggunakan botol kaca silinder, pisau (cutter) dan wadah pengaduk resin, sedangkan bahan yang dipergunakan adalah daun kering yang telah dihaluskan seperti bentuk tepung, additive PVAc adalah sebagai perekat, dan resin sebagai pelapis.

- Bahan daun kering yang telah dipersiapkan diletakkan pada wadah dan dicampurkan dengan additive PVAc, kemudian diaduk secara merata. Setelah merata, kemudian dibuat komposit tersebut menjadi pipih/plat datar dengan cara ditekan sampai mencapai ketebalan 1-2 mm.

- Siapkan pola bulat yang akan dibentuk. Komposit yang sudah dalam bentuk pipih, kemudian dibentuk sesuai pola bulat yang telah dipersiapkan dan direkatkan sehingga menutupi seluruh bagian. Komposit yang telah terbentuk bulat, kemudian di jemur pada panas matahari, sehingga menggering. Setelah mengering kemudian dilepaskan dari pola.

- Komposit yang telah mengering, kemudian dibersihkan dan dirapihkan dari sisa-sisa ataupun bentuk yang tudak rapih menggunakan pisau (cutter).

- Siapkan resin dan hardener dengan cara mencampur secara merata. Siapkan tempat pembibitan yang sudah kering dan diolehkan menggunakan resin ke seluruh bagian. Kemudian jemur sampai kering dan bersihkan beberapa bagian yang kurang baik.

- Setelah kering tempat siap untuk diisi air dan ikan sebagai tempat pembibitan ikan.

- Adapun gambar dari tempat pembibitan ikan dapat dilihat pada gambar di bawah ini.

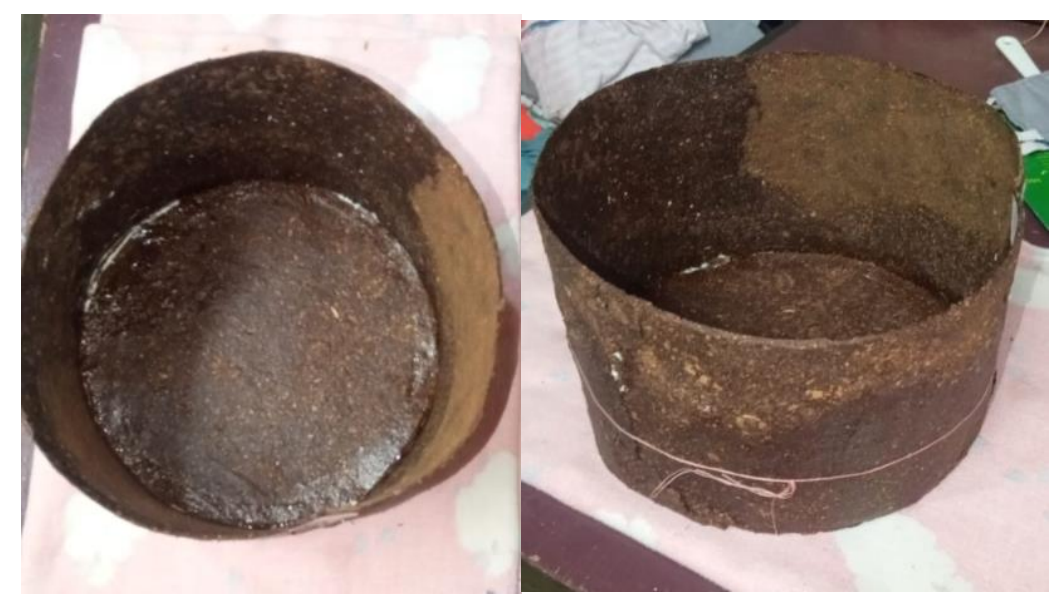

a.

b. 


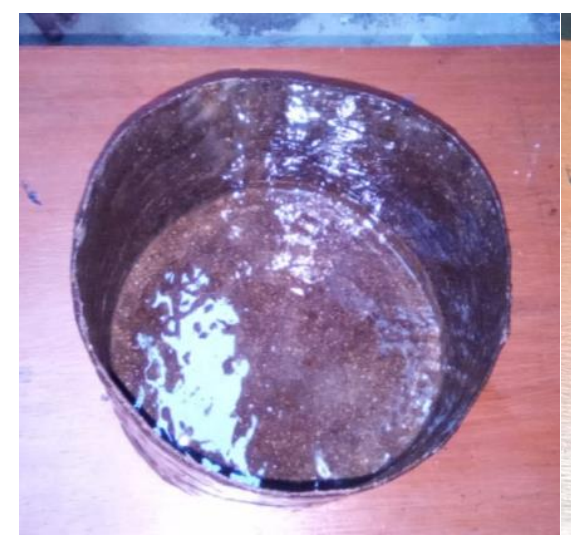

c.

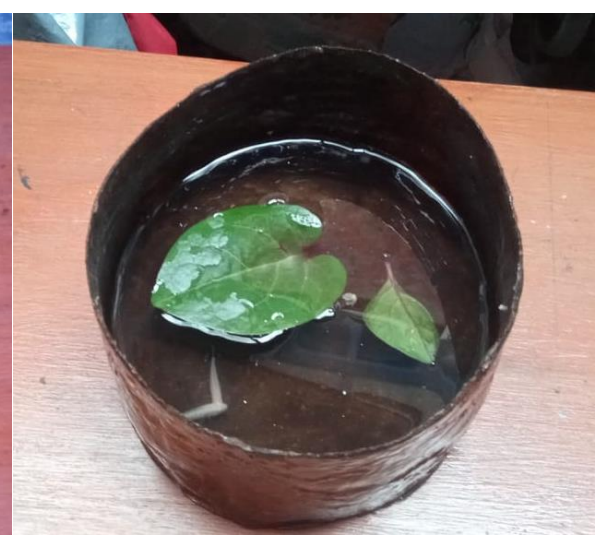

d.

Gambar 2 .

(a) Tempat Pembibitan Ikan Daun Kering, Tampak Atas Bahan di cetak dengan pola melingkar, (b) Tampak Samping Bahan di cetak dengan pola melingkar, (c) Tempat Pembibitan dilapisi resin,

(d) Tempat Pembibitan Ikan

\section{KESIMPULAN}

Daun kering yang telah diolah menjadi komposit dapat diproses dan dibentuk dengan manual berupa lembaran tipis/pipih dan dapat mudah dibentuk menjadi tempat pembibitan ikan. Tempat pembibitan ikan yang telah kering dari daun kering dan additive PVAc dilapisi kembali oleh resin diseluruh permukaannya dan akan menahan beban serta kebocoran dari air yang terdapat di tempat pembibitan ikan.

\section{Daftar Pustaka}

Hendrasarie, N. (2007). Kajian Efektifitas Tanaman Dalam Menjerap Kandungan Pb Di Udara. Jurnal Rekayasa Perencanaan, 3(2). https://core.ac.uk/download/pdf/12216725.pdf

Riskitavani, D. V. dan Purwani, K. I. (2013). Studi Potensi Bioherbisida Ekstrak Daun Ketapang (Terminalia catappa) terhadap Gulma Rumput Teki (Cyperus rotundus). Jurnal Sains dan Seni ITS, 2(2), 2337-3520. https://dx.doi.org/10.12962/j23373520.v2i2.3593

Nusantara, D. O., Pamungkas, S.W., Syaifudin, N. R., Kusuma, L. W., dan Fikri, J. (2017). Sistem Pakar Analisa Penyakit Pada Tanaman Cabai Merah Menggunakan Metode Backward Chaining. Semnasteknomedia, $5(1)$, 73-78. https://ojs.amikom.ac.id/index.php/semnasteknomedia/article/view/1664

Wandi, A. (2015). Pemanfaatan Limbah Daun Kering Menjadi Briket Untuk Bahan Bakar Tungku. Skripsi, Universitas Jember.

Amran, Y. (2015). Pemanfaatan Limbah Plastik Untuk Bahan Tambahan Pembuatan Paving Block Sebagai Alternatif Perkerasan Pada Lahan Parkir Di Universitas Muhammadiyah Metro, TAPAK, 4(2), 125-129.

Peraturan Presiden Indonesia No. 97/2017

Peraturan Menteri Negara Lingkungan Hidup Republik Indonesia Nomor 13 Tahun 2012

Setyorini, D., Saraswati, R., Anwar, E. K. (2006). Kompos, Pupuk Organik dan Pupuk Hayati, 11-40.

Rahardja, I. B., Ramadhan, A. I. (2019). Pemanfaatan Daun Nangka Kering Sebagai Tempat Alat Tulis Kantor (ATK). Jurnal Pengabdian Masyarakat Teknik (JPMT), 2(1), 1-6. https://jurnal.umj.ac.id/index.php/JPMT/article/view/6180

Khuluq, A. D. (2012). Potensi Pemanfaatan Limbah Tebu sebagai Pakan Fermentasi Probiotik. Buletin Tanaman Tembakau, Serat \& Minyak Industri, 4(1), 37-45. http://balittas.litbang.pertanian.go.id/images/pdf/vol43645.pdf 